\title{
PENERAPAN PEMBELAJARAN KOOPERATIF DALAM PEMBELAJARAN BAHASA JEPANG DI KELAS XII BAHASA SMA N 1 ABIANSEMAL
}

\author{
I.B.G.A.P.Kusuma, I.W.Sadyana, G.S.Hermawan \\ Prodi Pendidikan Bahasa Jepang, Universitas Pendidikan Ganesha \\ Singaraja \\ e-mail: kusuma.baqus@undiksha.ac.id \\ wayan.sadyana@undiksha.ac.id satya.hermawan@undiksha.ac.id
}

\begin{abstract}
Abstrak
Penelitian ini bertujuan untuk mendeskripsikan (1) penerapan pembelajaran bahasa Jepang dengan pembelajaran kooperatif di kelas XII Bahasa SMA N 1 Abiansemal, (2) kendala-kendala yang dihadapi dalam kegiatan pembelajaran bahasa Jepang dengan menggunakan strategi kooperatif di kelas XII Bahasa SMA N 1 Abiansemal. Subjek penelitian pada penelitian ini adalah guru pada mata pelajaran bahasa Jepang. Pengumpulan data dilakukan dengan metode observasi, wawancara, dan dokumentasi, kemudian dianalisis dengan metode deskriptif kualitatif. Hasil penelitian ini menunjukkan bahwa (1) Penerapan strategi kooperatif dalam pembelajaran bahasa Jepang di kelas XII bahasa SMA N 1 Abiansemal telah dilaksanakan oleh guru. Dalam pembelajaran bahasa Jepang pembelajaran kooperatif dilakukan pada kegiatan latihan pembuatan kalimat. Penggunaan strategi kooperatif yang telah digunakan oleh guru membuat siswa lebih aktif dalam belajar. (2) kendala yang dihadapi guru dalam mengimplementasikan strategi kooperatif dalam pembelajaran bahasa Jepang adalah kendala pemilihan sumber ajar, kendala dalam kegiatan kelompok, dan kendala dalam evaluasi.
\end{abstract}

Kata kunci : Bahasa Jepang, Strategi Kooperatif , Strategi Pembelajaran

\begin{abstract}
要旨
本研究は、（1）アビアンスマル第一高等学校の日本語学習におけるを協力的学習で研究する事であ る。（2）アビアンスマル第一高等学校の言語クラスの三年生における実施した共同学習の問題点で ある。調查対象は日本語教師である。データ収集方法は観察、インタビュー、及び文章化である。そ れを定性的な記述方法により分析した。その結果、（1）アビアンスマル第一高等学校の言語クラス の三年生における共同学習は教師により実施された。共同学習は基本練習に行われた。共同学習で学 生を積極的に行動させることができるようになった。（2）教師により共同方法による日本語授業の 問題は教材の選択、学習者の団体の活動、及び学習者の評価である。
\end{abstract}

キーワード；日本語、共同方法、教授法

\section{Pendahuluan}

Tinggi rendah mutu pendidikan tidak hanya dilihat dari nilai siswa tapi juga melalui proses pembelajaran untuk mendapatkan nilai tersebut. Terdapat empat komponen utama dalam pembelajaran, meliputi (1) situasi dan kondisi pembelajaran, (2) bahan ajar, (3) strategi pembelajaran, dan (4) hasil pembelajaran. Keempat komponen tersebut, salah satu yang mempengaruhi mutu pendidikan adalah strategi pembelajaran.

Strategi pembelajaran bahasa asing merupakan salah satu hal yang cukup menentukan keberhasilan dalam pembelajaran. Keberhasilan dari pembelajaran sangat berkaitan erat dengan strategi dan metode pembelajaran yang digunakan. Strategi 
pembelajaran merupakan perencanaan hal-hal yang akan dilakukan dalam kegiatan belajar mengajar untuk mencapai suatu tujuan pembelajaran dengan efektif dan efisien. Dengan adanya strategi yang jelas, proses pembelajaran akan terarah sehingga guru memiliki pedoman dan acuan bertindak yang sistematis dalam pelaksanaan pembelajaran yang berlangsung. Faktor yang memengaruhi pemilihan strategi pembelajaran tersebut antara lain karakteristik peserta didik, kompetensi dasar yang diharapkan, bahan ajar, waktu, sarana dan prasarana belajar serta kemampuan guru memilih dan menggunakan strategi pembelajaran itu sendiri.

Pelaksanaan strategi pembelajaran kooperatif membutuhkan partisipasi dan kerjasama dalam kelompok pembelajaran. Pembelajaran kooperatif dapat meningkatkan cara belajar siswa menuju belajar lebih baik, sikap tolong menolong dalam beberapa prilaku sosial. Tujuan utama dalam penerapan strategi pembelajaran kooperatif adalah agar peserta didik dapat belajar secara berkelompok bersama teman-temannya dengan cara saling menghargai pendapat dan memberikan kesempatan kepada orang lain untuk mengemukakan gagasannya dengan menyampaikan pendapat mereka secara berkelompok (Isjoni, 2010:21).

Berdasarkan hasil observasi yang peneliti lakukan di kelas SMA N 1 Abiansemal bahasa Jepang merupakan salah satu pelajaran bahasa asing yang diajarkan di SMA N 1 Abiansemal. Pelajaran bahasa Jepang di SMA N 1 Abiansemal diajarkan dari kelas X sampai kelas XII, tapi tidak diajarkan di kelas IPS. Dari hasil wawancara yang peneliti lakukan sebelum guru mengunakan strategi kooperatif guru pernah menggunakan strategi ekspositori tetapi di saat guru menggunakan strategi ini kebanyakan siswa tidak memperhatikan guru karena guru hanya fokus menjelaskan dengan ceramah sedangkan siswa hanya mendengarkan dan mencatat. Maka dari itu guru menggunakan strategi kooperatif di kelas XII karena strategi ini mengajarkan siswa untuk bersosialisasi dan tidak malu untuk mengajukan pendapat.

Berdasarkan uraian tersebut, penulis tertarik untuk melaksanakan penelitian dengan judul "Penerapan Strategi Kooperatif Dalam Pembelajaran Bahasa Jepang di kelas XII Bahasa SMA N 1 Abiansemal". Maka dari penelitian ini akan terlihat implementasi pembelajaran bahasa Jepang dengan strategi pembelajaran kooperatif dan kendala-kendala yang dihadapi dalam pembelajaran bahasa Jepang dengan menggunakan strategi kooperatif.

Berdasarkan latar belakang yang telah dipaparkan, maka berikut merupakan identifikasi masalah yang terdapat di kelas XII Bahasa SMA N 1Abiansemal yaitu, ada banyak strategi pembelajaran yang pemanfaatannya tergantung pada situasi dan kondisi, variasi materi dan pemilihan strategi pembelajaran, strategi pembelajaran dan pengelolaan kelas, dan dilihat dari tipe pembelajaran kooperatif, yang akan dilihat dalam penelitian ini bagaimana implementasi pembelajaran yang dilakukan guru di dalam kelas. Agar penelitian lebih terarah, maka peneliti perlu menggunakan pembatasan masalah antara lain, penelitian ini hanya melibatkan guru bahasa Jepang di SMA N 1 Abiansemal, penelitian ini memfokuskan pada strategi pembelajaran kooperatif yang digunakan guru bahasa Jepang di kelas XII Bahasa SMA N 1 Abiansemal.

Penelitian yang pertama adalah penelitian yang dilakukan oleh Rizka Anggia Ningtias (2016). Penelitian ini tentang penerapan strategi pembelajaran kooperatif dalam pembelajaran IPA di kelas IV MI Ma'arif NU 01. Penelitian ini bertujuan untuk mengetahui tentang penerapan strategi pembelajaran kooperatif dalam pembelajaran IPA di MI Ma'arif NU 01. Penelitian ini dilakukan dengan penelitian lapangan yang bersifat deskriptif kualitatif. Metode yang digunakan dalam pengumpulan data dalam penelitian ini adalah metode observasi, wawancara, dan dokumentasi. Penelitian yang kedua adalah penelitian yang dilakukan oleh Farid Hidayatullah (2016). Penelitian ini tentang penerapan strategi cooperative learning dalam pembelajaran bahasa Arab di panti asuhan muhammadiyah berbasis pesantren. Penelitian ini termasuk dalam penelitian deskriptif kualitatif. Objek dalam penelitian ini adalah proses penerapan strategi cooperative learning dalam pembelajaran 
bahasa Arab di kelas A dan B. Metode pengumpulan data dalam penelitian ini menggunakan metode observasi, wawancara, dan dokumentasi.

Menurut Hamruni (2012) strategi pembelajaran merupakan pola umum aktivitas guru dengan peserta didik termasuk penggunaan metode dan pemanfaatan berbagai sumber daya dalam perwujudan kegiatan belajar mengajar. Sedangkan, Purwiyuanti (2014) menyatakan strategi pembelajaran dapat diartikan sebagai perencanaan yang isinya mengenai rangkaian kegiatan yang telah didesain untuk mencapai tujuan pembelajaran tertentu. Jadi dapat disimpulkan strategi pembelajaran merupakan cara-cara yang digunakan oleh pendidik untuk mengajar sehingga peserta didik akan mudah untuk menerima dan memahami materi pembelajaran yang diberikan dan tujuan pembelajaran akan tercapai.

Pembelajaran kooperatif merupakan strategi belajar dengan sejumlah siswa sebagai anggota kelompok kecil yang masing-masing tingkat kemampuannya berbeda (Riadi, 2012). Strategi belajar ini mengharuskan setiap siswa di dalam kelompok harus saling bekerja sama untuk memahami materi pelajaran. Pembelajaran kooperatif bisa digunakan terutama apabila guru mengharapkan semua siswa (tidak hanya yang pintar) untuk mencapai kesuksesan dalam pembelajaran mereka, guru menginginkan siswanya saling bertukar informasi kemudian melihat apakah mereka bisa saling belajar dan membantu satu sama lain, serta guru ingin mengembangkan dan meningkatkan sikap saling menghargai kelebihan dan kelemahan masing-masing siswa.

Sedangkan Padmadewi (2012) menyatakan bahwa pembelajaran kooperatif merupakan teknik pembelajaran yang mendorong siswa untuk bekerja bersama untuk memaksimalkan pembelajarannya sendiri dan pembelajaran dengan teman sejawat. Ada lima unsur dasar yang dimasukkan ke dalam pembelajaran kerja kelompok agar bisa dikategorikan sebagai pembelajaran kooperatif yaitu (1) saling ketergantungan secara positif, (2) interaksi tatap muka, (3) akuntabilitas individu sehingga semua siswa bertanggung jawab di dalam proses pembelajaran dalam kelompok, (4) penggunaan keterampilan interpersonal yang tepat, dan (5) analisis hasil belajar secara berkelompok. Alasan guru untuk menugaskan siswa bekerja secara kooperatif adalah kerja siswa secara berkelompok akan sukses secara akademis daripada bekerja sendiri.

Pembelajaran bahasa Jepang di Indonesia umumnya diajarkan sebagai bahasa asing. Bahasa asing dalam bidang pengajaran bahasa berbeda dengan bahasa kedua.Bahasa asing merupakan bahasa yang tidak digunakan sebagai alat komunikasi di negara tertentu dimana bahasa tersebut diajarkan.Padmadewi (2012) bahasa asing merupakan bahasa selain bahasa ibu yang sedang dipelajari oleh peserta didik, dimana bahasa asing tersebut belum dikenal oleh peserta didik. Jadi, belajar bahasa pada hakikatnya sama halnya dengan belajar berkomunikasi. penggunaan bahasa asing di dalam kelas oleh guru memberikan pengaruh positif. Dengan menggunakan bahasa asing secara terus menerus dapat meningkatkan kemampuan komunikasi guru serta meningkatkan kemampuan menyimak siswa.

Menurut Brown (2007) pembelajaran merupakan proses interaksi antara peserta didik dengan pendidik dan sumber belajar yang terjadi di suatu lingkungan belajar yang bertujuan untuk membantu orang belajar. Maka, ada lima asumsi yang mendukung pembelajaran tersebut, yaitu (1) pembelajaran harus direncanakan agar memperlancar proses belajar peserta didik, (2) fase pendek maupun fase panjang dimasukkan ke dalam rancangan beajar, (3) perencanaan dalam pembelajaran harusnya tidak asal-asalan dan tidak sematamata menyediakan lingkungan asuh saja, (4) usaha pembelajaran mesti dirancang dengan rancangan sistem, dan (5) pembelajaran harus dikembangkan sesuai pengetahuan mengenai bagaimana orang itu belajar.

Strategi pembelajaran bahasa asing adalah pikiran dan tindakan yang menggunakan individu untuk mencapai tujuan pembelajaran. Dan tujuan dalam hal ini adalah belajar secara mandiri. Definisi ini dianggap cocok karena pertama, strategi digambarkan sebagai rencana dan bukan aktifitas. Rencana biasanya kita buat secara sadar. Jika kita mengajarkan strategi maka yang menjadi syarat utama adalah mengajarkan strategi yang berfokus kepada tujuan. 
Pembelajaran dengan teknik ceramah dan penerjemahan (konvensional) lebih terfokus kepada bahasa sebagai sebuah struktur sistem pola gramatikal, materi bahasa dipilih berdasarkan pada kriteria linguistik, bahasa dilihat sebagai suatu kesatuan yang dipersatukan dengan meletakkan pola yang bersifat gramatikal, bahasa yang digunakan cenderung formal, keberhasilan peserta didik diukur dari kemampuan peserta didik membuat kalimat formal dengan benar, keterampilan peserta didik hanya ditekankan pada keterampilan membaca dan menulis, pembelajaran cenderung berpusat pada guru dan konsentrasi bahasa lebih ditekankan pada format ucapan dibanding pada inti bahasa itu sendiri (Nunan,1989:26).

Untuk mencapai sasaran hasil pembelajaran yang sesuai dengan standar kompetensi yang telah ada diperlukan penguasaan yang baik dalam empat keterampilan berbahasa yang komunikatif. Proses tersebut akan menjadi sempurna apabila peserta didik memberikan respon positif, maka diperlukan teknik yang kooperatif. Hal iniah yang menjadi pertimbangan khusus agar para guru menggunakan teknik dalam metode pembelajaran kooperatif. Pembelajaran kooperatif (cooperative learning) adalah pembelajaran yang menetapkan peserta didik untuk selalu bekerjasama, bertukar pikiran dan pengalaman juga saling membantu satu sama lain secara kooperatif dalam kelompok-kelompok kecil (Lie,2004:29).

Dalam proses pembelajaran bahasa Jepang yang dilakukan di sekolah maupun lembaga pendidikan, guru hendaknya mengajarkan kepada peserta didik bahasa Jepang mulai dari pembelajaran bahasa Jepang dasar. Pembelajaran bahasa Jepang dasar merupakan pembelajaran yang mengajarkan hal-hal dasar dari bahasa Jepang, seperti huruf, pelafalan, kosa kata. terdapat tiga tahapan yang perlu dilakukan saat pembelajaran bahasa Jepang dasar yakni,分かる(pemahaman), 覚える(mengingat),使える(penggunaan).

Tahapan yang kedua Kihon renshuu yang merupakan latihan dasar yang berupa pengulangan. Pada latihan dasar ini guru juga memberikan latihan tanya jawab serta latihan mengganti kata. Pada tahapan ini guru akan memberikan latihan dasar kepada peserta didik berupa guru mencontohkan kosa kata kemudian peserta didik akan mengikutinya dan mengucapkan kosa kata itu kembali dengan pengulangan.

Tahapan yang ketiga yaitu ouyou renshuu yang merupakan proses pembelajaran untuk latihan penerapan dari materi-materi pembelajaran yang telah diajarkan kepada perserta didik. Siswa diajarkan untuk mengingat tata bahasa yang baru, kemudian dapat menggunakannya dalam berkomunikasi. Pada pembelajaran ini siswa dilatih untuk menggunakan tata bahasa yang diingat dengan mengkomunikasikan pada situasi yang sebenarnya.

Cooperative learning berasal dari kata cooperative yang artinya mengerjakan sesuatu secara bersama-sama dengan saling membantu satu sama lain sebagai satu kelompok atau satu tim. Slavin (1995) mengemukakan, "In cooperative learning methods, stdents work together in four member teams to master material initially presented by the teacher". Dari uraian tersebut dapat dikemukakan bahwa cooperative learning adalah suatu model pembelajaran dimana sistem belajar dan bekerja dalam kelompok-kelompok kecil yang berjumlah 4-6 orang secara kolaboratif sehingga dapat merangsang siswa lebih bergairah dalam belajar.

Pelaksanaan model cooperative learning membutuhkan partisipasi dan kerjasama dalam kelompok pembelajaran. Cooperative learning dapat meningkatkan cara belajar siswa menuju belajar lebih baik, sikap tolong-menolong dalam beberapa perilaku sosial. Tujuan utama dalam penerapan model belajar mengajar cooperative learning adalah agar peserta didik dapat belajar secara berkelompok bersama teman-temannya dengan cara saling menghargai pendapat dan memberikan kesempatan kepada orang lain untuk mengemukakan gagasannya dengan menyampaikan pendapat mereka secara berkelompok. Pembelajaran kooperatif disusun dalam sebuah usaha untuk meningkatkan partisipasi siswa, memfasilitasi siswa dengan pengalaman sikap kepemimpinan dan membuat keputusan dalam kelompok, serta memberikan kesempatan pada siswa untuk berinteraksi dan belajar bersama-sama siswa yang berbeda latar belakangnya, jadi dalam pembelajaran kooperatif siswa berperan ganda yaitu sebagai siswa ataupun sebagai guru. 
Pentingnya tujuan kelompok dan tanggung jawab individu adalah dalam memberikan insentif kepada siswa untuk saling membantu satu sama lain dan untuk saling mendorong untuk melakukan usaha yang maksimal (Slavin, 1993). Jika nilai siswa cukup baik sebagai kelompok, dan kelompok hanya akan berhasil dengan memastikan bahwa semua anggota mempelajari materinya, maka anggota kelompok akan termotivasi untuk saling mengejar (Slavin, 2010: 81-82).

Pembelajaran kooperatif dapat menjadi metode pembelajaran yang efektif akan tetapi jika metode ini tidak dikonstruksikan dengan baik akan menimbulkan efek "free rider". Efek free rider yaitu suatu kondisi dimana beberapa anggota kelompok mengerjakan semua atau sebagai pekerjaan dalam pembelajaran sedangkan yang lainnya jalan terus, tidak melakukan aktifitas. Artinya aktifitas belajar hanya dilakukan oleh sebagian anggota kelompok saja. Kondisi ini dapat mengurangi hasil maksimal dari pembelajaran kooperatif. Akan tetapi, kondisi tersebut dapat diminimalisir jika guru dapat meyakinkan siswa bahwa mereka yang telah dikelompokkan itu memiliki tanggung jawab individu selama pelajaran berlangsung.

\section{Metode}

Berdasarkan dengan permasalahan yang diangkat, yakni tentang penerapan strategi kooperatif dalam pembelajaran bahasa Jepang di kelas XII Bahasa SMA N 1 Abiansemal, penelitian ini menggunakan rancangan penelitian deskriptif kualitatif. Data dalam penelitian ini diperoleh melalui tiga cara yaitu melalui obserfasi, wawancara, dan dokumentasi. Pengumpulan data melalui obserfasi dan wawancara dianalisis, kemudian dideskripsikan secara kualitatif. Selanjutnya pengumpulan data melalui dokumentasi digunakan untuk mendapatkan data yang valid dan diperlukan dalam penelitian.

\section{Hasil dan Pembahasan}

Hasil penelitian dari penerapan strategi kooperatif dalam pembelajaran bahasa Jepang di SMA N 1 Abiansemal diperoleh melalui hasil observasi dan hasil wawancara. Observasi yang dilakukan berpedoman pada pedoman observasi untuk mengamati proses pembelajaran bahasa Jepang di kelas XII Bahasa SMA N 1 Abiansemal. Sedangkan wawancara yang dilakukan adalah wawancara terbuka untuk tidak mengikat jawaban dari narasumber dalam menjawab pertanyaan yang diajukan. Karena dalam wawancara tersebut narasumber diminta lebih banyak untuk memberikan penjelasan lengkap mengenai penerapan strategi kooperatif dalam proses pembelajaran.

Hasil observasi pertama dilakukan di kelas XII Bahasa pada hari senin, 17 september 2018, jam ke 1-2 yaitu dari jam 07.00-08.20. Pada saat itu, pelajaran bahasa Jepang mempelajari tema（ほっかいどうはいまふゆです).

a. Pendahuluan

Sebelum memulai pembelajaran ketua kelas mengarahkan semua siswa untuk mengucapkan salam panganjali (om swastiastu) dan guru pun menjawab sedemikian rupa. Selanjutnya guru memberikan salam menggunakan bahasa Jepang seperti ohayou gozaimasu dan siswa juga menjawab dengan mengucapkan ohayou gozaimasu.

b. Kegiatan Inti

Di kegiatan inti ini guru memulainya dengan bertanya tentang ada berapa musim di Indonesia dan melakukan tanya jawab singkat dengan siswa. Lalu lanjut menjelaskan kosa kata tentang musim di Indonesia, musim di Jepang, kondisi udara, dan cuaca di Jepang. Di Indonesia ada dua musim yaitu うき(musim hujan) dan かんき(musim panas)、sedangkan di Jepang ada empat musim yaitu はる(musim semi)、なつ(musim panas)、あき(musim gugur) 、ふゆ(musim salju)、selain itu terdapat juga kondisi udara yaitu あたたかい(hangat)、あつ い(panas)、すずしい(sejuk)、さむい(dingin) dan cuaca di Jepang yaitu はれています(cerah) 、くもっています(mendung)、あめがふっています(hujan)、ゆきがふっています(salju).

Setelah paham dengan kosa kata tersebut selanjutnya guru membagi siswa ke dalam kelompok kecil yang didalam setiap kelompok berisi jenis kelamin yang berbeda dan juga dipilih berdasarkan kemampuan siswa. Lalu guru melanjutkan dengan memberikan pola 
kalimat yaitu KB (Tempat) はいま KS(Musim) です。Dan guru memberikan contoh kalimat seperti インドネシアはいまうきです。Setelah siswa paham dengan pola kalimat ini siswa disuruh untuk merundingkan dengan kelompok masing-masing untuk membuat beberapa kalimat seperti pola kalimat yang sudah diajarkan, selanjutnya guru menunjuk salah satu anggota kelompok untuk membacakan kalimat yang sudah dibuat bersama kelompoknya dan kelompok lain disuruh untuk mengartikan arti dari kalimat tersebut.

c. Penutup

Di kegiatan penutup ini guru memberikan kesimpulan tentang materi yang telah dijelaskan dan memberikan kesempatan kepada siswa untuk bertanya mengenai apa yang belum mereka pahami dalam pelajaran tadi. Setelah itu guru memberikan pekerjaan rumah yang ada di buku, tugasnya hanya mengisi (ふくしゅう)yang ada di buku lalu disetor di pertemuan berikutnya. Setelah itu ketua kelas mengarahkan semua siswa untuk mengucapkan salam penutup yaitu parama santih (om santih, santih, santih om).

Hasil observasi kedua dilakukan di kelas XII Bahasa pada hari selasa, 18 september 2018, jam ke 7-8 yaitu 11.20-12.20. pada saat itu, pelajaran bahasa Jepang mempelajari tema tentang（かんこうち）.

a. Pendahuluan

Pada saat guru memasuki ruang kelas, ketua kelas mengarahkan seluruh siswa untuk berdiri dan mengucapkan panganjali umat (om swastiastu) dan guru pun menjawab sedemikian rupa. Selanjutnya guru memberikan salam menggunakan bahasa Jepang seperti ohayou gozaimasu dan siswa juga menjawab dengan mengucapkan ohayou gozaimasu dan guru pun mempersilahkan siswa untuk duduk. Setelah itu guru melakukan presensi kepada seluruh siswa dengan memanggil satu per satu nama siswa.

b. Kegiatan Inti

Pada kegiatan inti ini guru memulainya dengan bertanya-tanya tentang objek wisata yang siswa ketahui dan daerah wisata yang mereka pernah kunjungi dan juga beberapa pulau di Indonesia. Selanjutnya guru pun mulai menyebutkan tempat wisata yang ada di dalam buku dan semua siswa memperhatikan. Tempat wisata yang dijelaskan seperti しょくぶつえん (kebun raya)、おんせん(permandian air panas)、たき(air terjun)、はくぶつかん(museum)、 おうきゅう (keraton). Setelah semua paham tentang kosa kata tersebut lalu guru memberikan lagi kosa kata tentang daerah wisata dan pulau di Indonesia yaitu Kuta, Ubud, Kintamani, Bogor, Tana Toraja, Monas, Borobudur, Gunung Bromo. Dan beberapa pulau yang ada di Indonesia seperti Sumatera, Jawa, Bali, Kalimantan, Sulawesi.

Setelah semua siswa paham semua kosakata yang telah diberikan itu guru melanjutkan dengan membagi siswa ke dalam kelompok kecil yang sudah dibentuk sebelumnya, setelah siswa membentuk kelompok guru meminta siswa untuk menemukan beberapa kosa kata yang berkaitan dengan materi yang diberikan setelah itu guru mulai memberikan pola kalimat. Pola kalimat yang pertama diberikan adalah KB(tempat)に KB1(tempat wisata)や KB2 (tempat wisata) などがあります。Guru juga memberikan contoh dari pola kalimat yang sudah diberikan. Contoh: ジャカルタにモナスやタマン。ミニなどがあります。 kemudian guru mulai menyuruh semua kelompok untuk berdiskusi untuk membuat kalimat sesuai pola kalimat yang telah diberikan. Lalu guru menunjuk salah satu anggota kelompok untuk membacakan hasil diskusi mereka untuk membuat sebuah kalimat.

c. Penutup

Di kegiatan penutup ini guru memberikan kesimpulan tentang materi yang telah dijelaskan dan memberikan kesempatan kepada seluruh siswa untuk bertanya mengenai apa yang belum mereka pahami dalam pelajaran yang telah diberikan. Di pertemuan ini guru tidak memberikan tugas kepada siswa karena waktu sudah menunjukan jam pulang sekolah. Setelah itu ketua kelas mengarahkan semua siswa untuk mengucapkan salam penutup yaitu parama santih (om santih, santih, santih om). 
Hasil observasi ketiga dilakukan di kelas XII Bahasa pada hari senin, 8 oktober 2018, jam ke 1-2 yaitu jam 07.00-08.20. pada saat itu, pelajaran bahasa Jepang mempelajari tema tentang (どうしたんですか)。

a. Pendahuluan

Sama seperti observasi sebelum-sebelumnya pada saat guru memasuki ruang kelas, ketua kelas mengarahkan seluruh siswa untuk berdiri dan mengucapkan panganjali umat (om swastiastu) dan guru pun menjawab sedemikian rupa. Selanjutnya guru memberikan salam menggunakan bahasa Jepang seperti ohayou gozaimasu dan siswa juga menjawab dengan mengucapkan ohayou gozaimasu dan gurupun mempersilahkan siswa unduk duduk.

b. Kegiatan Inti

Pada kegiatan inti ini guru memulainya dengan bertanya-tanya tentang bagian-bagian tubuh manusia dengan menggunakan bahasa Indonesia. Selanjutnya guru pun mulai menyebutkan bagian-bagian tubuh dengan menggunakan bahasa Jepang seperti あたま（ kepala)、かた(bahu)、くち(mulut)、て(tangan)、おなか(perut)、こし(bokong)、あし(kaki), はな（hidung）、は(gigi)、め(mata)、みみ(telinga)、のど(tenggorokan). Setelah itu guru memberikan kosa kata tentang kondisi kesehatan yaitu あたまがいたい（sakit kepala）,おな かがいたい(sakit perut)、のどがいたい(sakit tenggorokan)、ぐあいがわるい(kondisi buruk) 、ねつがあります(demam)、せきがでます(batuk)、かぜをひきました(masuk angin)、けが をしました(terluka). Setelah itu guru menunjuk satu per satu siswa untuk menjawab pertanyaan tentang bagian-bagian tubuh dan juga kondisi kesehatan.

Setelah semua siswa paham semua kosakata yang telah diberikan itu guru melanjutkan dengan membagi siswa ke dalam kelompok kecil yang sudah dibentuk sebelumnya. Setelah itu guru memberikan lagu yang ada di buku dan bernyanyi bersama-sama beberapa kali. Setelah itu guru melanjutkan dengan memberikan pola kalimat, pola kalimat yang pertama diberikan adalah KK(bentuk kamus/-ta) / KS んです。Dan contoh kalimatnya yaitu あたまが いたいんです。Dan guru mulai menyuruh semua kelompok untuk berdiskusi untuk membuat kalimat sesuai pola kalimat yang telah diberikan. Lalu guru menunjuk salah satu anggota kelompok untuk membacakan hasil diskusi mereka untuk membuat sebuah kalimat.

c. Penutupan

Di kegiatan penutup ini guru memberikan kesimpilan tentang materi yang telah dijelaskan dan memberikan kesempatan kepada seluruh siswa untuk bertanya mengenai apa yang belum mereka pahami dalam pelajaran yang telah diberikan. Di pertemuan ini guru memberikan tugas untuk siswa membuat huruf kanji yang ada di buku pelajaran. Setelah itu ketua kelas mengarahkan semua siswa untuk mengucapkan salam penutup yaitu parama santih (om santih, santih, santih om).

Hasil observasi keempat dilakukan di kelas XII Bahasa pada hari senin, 15 oktober 2018, jam ke 1-2 yaitu 07.00-08.20. pada saat itu, pelajaran bahasa Jepang mempelajari tema tentang (なにがほしいですか)。

a. Pendahuluan

Di kegiatan pendahuluan ini sama seperti observasi sebelum-sebelumnya pada saat guru memasuki ruang kelas, ketua kelas mengarahkan seluruh siswa untuk berdiri dan mengucapkan panganjali umat (om swastiastu) dan guru pun menjawab sedemikian rupa. Selanjutnya guru memberikan salam menggunakan bahasa Jepang seperti ohayou gozaimasu dan siswa juga menjawab dengan mengucapkan ohayou gozaimasu dan guru pun mempersilahkan siswa unduk duduk.

b. Kegiatan Inti

Pada kegiatan inti ini guru memulainya dengan bertanya-tanya tentang barang-barang yang diinginkan dan semua siswa menjawab sesuai keinginan mereka. Lalu guru menyebutkan kosa kata yang ada di buku seperti コンピューター (komputer), DVD ポレー ヤー（DVD），おかね（uang），けいたいでんわ（handphone）,スタレオ(speaker) dan guru menambahkan beberapa kosakata dengan memberikan gambar yang telah disiapkan oleh guru. Setelah semua siswa paham semua kosakata yang telah diberikan itu guru 
melanjutkan dengan membagi siswa ke dalam kelompok kecil yang sudah dibentuk sebelumnya. Setelah siswa membentuk kelompok guru meminta siswa untuk menemukan kosakata yang berkaitan dengan materi pembelajaran. Lalu setelah siswa menemukan beberapa kosa kata guru mulai memberikan pola kalimat. Pola kalimat yang pertama diberikan adalah KB がほしいです。Dan guru juga memberikan contoh dari pola kalimat yang sudah diberikan. Contoh: わたしはおか衫がほしい゙す。 Setelah itu guru mulai menyuruh semua kelompok untuk berdiskusi untuk membuat kalimat sesuai pola kalimat yang telah diberikan. Lalu guru menunjuk salah satu anggota kelompok untuk membacakan hasil diskusi mereka untuk membuat sebuah kalimat. Sedangkan kelompok lain disuruh mendengarkan untuk selanjutnya mengartikan arti dari kalimat yang dibacakan.

c. Penutup

Di kegiatan penutup ini guru memberikan kesimpulan tentang materi yang telah dijelaskan dan memberikan kesempatan kepada seluruh siswa untuk bertanya mengenai apa yang belum mereka pahami dalam pelajaran yang telah diberikan. Setelah itu guru memberikan tugas untuk menulis kanji (latihan kanji 7) untuk diperlihatkan di pertemuan selanjutnya. Setelah itu ketua kelas mengarahkan semua siswa untuk mengucapkan salam penutup yaitu parama santih (om santih, santih, santih om).

Penerapan strategi kooperatif dalam pembelajaran bahasa Jepang di kelas XII Bahasa SMA N 1 Abiansemal telah dilaksanakan oleh guru. Dalam pembelajaran bahasa Jepang pembelajaran kooperatif dilakukan pada kegiatan ouyou renshu di latihan pengayaan (つかえる). Dilihat dari kegiatan pembelajarannya yang diberikan oleh guru yang mulai membagi kelompok setelah kegiatan kihon renshu.

Pembelajaran kooperatif dilakukan dengan cara guru membagi siswa dalam proses pembelajaran berlangsung pembagian kelompok dilakukan dengan cara guru memilih siswa berdasarkan kemampuan belajar siswa dan juga jenis kelamin. Dalam pembelajaran kooperatif siswa diminta untuk bekerjasama dengan teman di dalam satu kelompok mereka, hal ini dilakukan dengan tujuan agar siswa bisa lebih aktif dalam mengikuti pembelajaran dan agar siswa bisa beinteraksi dengan teman dalam satu kelompoknya. Dalam pembelajaran kooperatif di pendahuluan hanya guru yang berbicara dan setelah masuk di kegiatan inti guru membentuk siswa ke dalam kelompok. Dalam kegiatan inti ini lebih banyak siswa yang melakukan kegitan berbicara daripada guru karena guru hanya memberi pola kalimat dan siswa diminta untuk berdiskusi bersama teman satu kelompok mereka untuk membuat kalimat sesuai denga pola kalimat yang diberikan. di kegiatan penutup kembali guru yang mengambil alih pembelajaran dan sekaligus menutup pembelajarn.

Pembelajaran kooperatif dilakukan karena dilihat dari karakteristik siswa yang pada saat guru menggunakan strategi ekspositori dalam melakukan proses pembelajaran guru meminta siswa untuk bertanya tidak satupun ada siswa yang mau bertanya dan juga disaat guru meminta siswa untuk membuat contoh kalimat hanya beberapa siswa yang mau untuk membuat contoh kalimat. Maka dari itu guru memilih strategi kooperatif untuk digunakan dalam mengajar agar siswa bisa berdiskusi saat melakukan pembelajara.

Dari sekian banyak tipe strategi pembelajaran kooperatif pada pembelajaran bahasa Jepang di kelas XII Bahasa SMA N 1 Abiansemal lebih banyak menggunakan strategi kooperatif tipe STAD (Student Team Achievement Divisions) yaitu pembelajaran yang menempatkan empat orang menjadi satu tim yang merupakan campuran menurut tingkat kinerjanya, jenis kelamin dan suku. Tipe ini digunakan oleh guru karena dilihat dari karakteristik siswa yang enggan untuk mau berbicara saat guru mengajukan pertanyaan dan ketika guru menyuruh menbuat suatu contoh kalimat. Di dalam kegiatan pembelajaran guru menyajikan pelajaran kemudian siswa diminta untuk bekerja dalam tim untuk memastikan bahwa seluruh anggota tim telah menguasai pelajaran tersebut. Dan diakhirnya pembelajaran semua siswa akan diminta mengerjakan tes individu dan dari hasil tes individu tersebut nilai akan digabungkan untuk menjadi nilai kelompok.

Strategi pembelajaran kooperatif tipe STAD (Student Team Achievement Divisions) yang dilakukan oleh guru di dalam kelas jika dilihat dari kegiatan pembelajaran guru 
mengkolaborasikan dengan discovery learning. Ini dilihat dari cara guru mengajar dengan menyuruh siswa untuk menemukan kosa kata yang berkaitan dengan pembelajaran dan juga siswa membuat kalimat sesuai contoh yang diberikan dan juga membuat percakapan seperti yang diperintahkan guru.

Dari hasil observasi dan wawancara penerapan strategi kooperatif tipe STAD (Student Team Achievement Divisions) yang digunakan dalam pembelajaran kelas XII Bahasa SMA N 1 Abiansemal hasilnya membuat siswa belajar lebih aktif di dalam kelas karena siswa lebih berani mengungkapkan pendapat mereka ke kelompoknya bukan langsung ke seluruhan siswa dan di dalam kelompok mereka mendiskusikan semua pendapat yang diajukan masing-masing anggota kelompok. Setelah itu hasil diskusi mereka baru dibacakan ke seluruh kelompok. Dan juga siswa lebih berani menanyakan sesuatu yang mereka belum mengerti ke teman yang sudah mengerti daripada mereka menanyakan ke guru langsung. Kemudian pelajaran lebih cepat diserap oleh siswa karena siswa berdiskusi dengan teman sekelompoknya. daripada guru menggunakan strategi pembelajaran ekspositori, siswa hanya diam memperhatikan semua penjelasan guru. Jadi penerapan strategi kooperatif tipe STAD (Student Team Achievement Divisions) yang digunakan membuat siswa lebih paham terhadap pembelajaran yang diberikan dan juga membuat nilai siswa memuaskan.

\section{Simpulan dan Saran}

Berdasarkan hasil penelitian dan pembahasan mengenai penerapan strategi kooperatif dalam pembelajaran bahasa Jepang di kelas XII Bahasa SMA N 1 Abiansemal dapat disimpulkan sebagai berikut.

1. Penerapan strategi kooperatif tipe STAD yang digunakan oleh guru sudah sangat efektif untuk membuat siswa paham dengan materi yang diberikan dan untuk meningkatkan nilai ujian nasional dari tahun 2014 sampai 2018.

2. Kendala yang dihadapi guru dalam mengajar menggunakan kooperatif tipe STAD ini adalah kurangnya LCD di dalam kelas untuk menyampaikan materi pembelajaran dan juga kebanyakan siswa dalam mengobrol pada saat diskusi. Tapi dapat diatasi dengan guru mengacak menunjuk siswa untuk menjawab pertanyaan agar siswa fokus dalam berdiskusi.

Berdasarkan temuan selama melaksanakan penelitian ini, maka akan disampaikan beberapa saran, yakni sebagai berikut.

1. Guru bahasa Jepang di kelas XII Bahasa SMA N 1 Abiansemal hendaknya mempu menjelaskan materi dengan menggunakan media yang lebih menarik agar siswa lebih semangat melaksanakan pembelajaran di dalam kelas.

2. Perlu diadakannya penelitian sejenis terkait dengan penerapan strategi pembelajaran agar dapat dijadikan acuan dalam memilih strategi pembelajaran untuk meningkatkan minat siswa untuk belajar.

\section{DAFTAR PUSTAKA}

Hamruni, $\quad$ 2012. Strategi Pembelajaran. Yogyakarta : Insan Madani.

Ningtias, A.2016. Penerapan Strategi Pembelajaran Kooperatif dalam Pembelajaran IImu Pengetahuan Alam (IPA) di Mi Ma "Arif NU 01 Bale Raksa Kecamatan Karang Moncol Kabupaten Purbalingga".Tersedia pada https://www.repository.iainpurwokerto.ac.id.

Padmadewi, M.A,2012. Strategi Pembelajaran Bahasa. Singaraja.

Purwiyuanti. 2014.Strategi Pembelajaran Bahasa Jepang oleh Guru di SMA 11 Semarang. Tersedia pada http://lib.unnes.ac.id/20890/1/2302407048-S.pdf

Slavin, $\quad$ Robert E.2010. Cooperative Learning; Teori, Riset dan Praktik.Bandung:Nusa

Media 
JPBJ, Vol.5 No.3 Oktober 2019 